\title{
PEGAS BELAJAR Application for Tracing Student's Learning Styles In Senior High School
}

\author{
Ramli \\ Bimbingan Konseling, SMP Negeri 19 Makassar, Indonesia \\ Email: conselor12.bk@gmail.com \\ Sulaiman Samad \\ Bimbingan Konseling, Universitas Negeri Makassar, Indonesia \\ Email: essamad@gmail.com
}

(Received: 30-May-2020; Reviewed: 03-August-2020; Accepted: 16-September-2020; Published: 29-December-2020)

\begin{abstract}
The research aims to determine 1) the description of the level of learning needs of the Learning Spring as a medium for tracing the learning styles of students in high schools, 2) the prototype of the Learning Spring as a medium for tracing the learning styles of students in high schools, and 3) the level of validity and practicality of Learning Spring as a medium for tracing. Student learning styles in high school. Using this type of development research with the ADDIE Model. Collecting data through interviews needs analysis questionnaires and trial questionnaires, with qualitative and quantitative data analysis. Trial phase with One to one Trial and Small Group Trial. The subject of validity testing to experts and practitioners and practicality test to teachers and students. The results showed 1) the level of need for Learning Spring as a medium for tracing student learning styles in high schools is in the high category, 2) the prototype Learning Spring as a medium for tracking student learning styles in high schools in the form of websites and guidebooks, and 3) validity The media through one to one trial to experts and practitioners shows a very high level of validity, the practicality of the media through a small group trial to teachers and students also shows a very high level of practicality. This shows that learning springs as a medium for tracing student learning styles have adequate content, presentation, language and graphic appropriateness.
\end{abstract}

Keywords: learning spring; website; learning style; experiential learning

Abstrak: Penelitian bertujuan untuk mengetahui 1) gambaran tingkat kebutuhan Pegas Belajar sebagai media penelusuran gaya belajar siswa di sekolah menengah atas 2) prototype Pegas Belajar sebagai media penelusuran gaya belajar siswa di sekolah menengah atas dan 3) tingkat validitas dan kepraktisan Pegas Belajar sebagai media penelusuran gaya belajar siswa di sekolah menengah atas. Menggunakan jenis penelitian pengembangan dengan Model ADDIE. Pengumpulan data melalui wawancara, angket analisis kebutuhan dan angket ujicoba, dengan analisis data kualitatif dan kuantitatif. Tahap ujicoba dengan One to one Trial dan Small Group Trial. Subjek uji validitas kepada ahli dan praktisi, dan uji kepraktisan kepada guru dan siswa. Hasil penelitian menunjukkan 1) tingkat kebutuhan Pegas Belajar sebagai media penelusuran gaya belajar siswa di sekolah menengah atas berada pada kategori tinggi, 2) prototype Pegas Belajar sebagai media penelusuran gaya belajar siswa di sekolah menengah atas dalam bentuk website dan buku panduan, dan 3) validitas media melalui one to one trial kepada ahli dan praktisi menunjukkan tingkat validitas sangat tinggi, kepraktisan media melalui small group trial kepada guru dan siswa juga menunjukkan tingkat kepraktisan sangat tinggi. Hal ini menunjukkan bahwa pegas belajar sebagai media penelusuran gaya belajar siswa memiliki kelayakan isi, penyajian, kebahasaan dan kegrafikan yang sangat memadai.

Kata kunci: pegas belajar; website; media; gaya belajar; experential learning 


\section{INTRODUCTION}

Learning is an activity shown by a relatively long-lasting behaviour change in a person due to experience (Parnawi, 2019). According to Kolb (2014), Experiential Learning is the process whereby development occurs. It means learning is a process in which development occurs. The development in question is a change in behaviour that occurs due to interaction with the environment (Maunah, 2014; Nurjan, 2016). Changes in a person after going through the learning process are the goal of education, namely developing potential. The potential that develops from learning outcomes will be seen from a capable, independent, creative person with good attitudes and habits. So, the learning process has an urgent role in the implementation of educational discipline to shape one's self-change (Abdullah, 2015; Maunah, 2014).

The learning process in education delivery is seen as adding and accumulating knowledge, which focuses on intellectual education. In other words, in a simple definition, learning is the process of gaining competence and understanding (Khalil \& Ebner, 2015). School as a place to obtain knowledge plays a role in the activities of providing knowledge and selfdevelopment and maximizing the potential of students. Learning activities have their own characteristics that each person is different. Everyone has a characteristic in receiving or absorbing information as a process of gaining knowledge. Everyone carries out learning and thinking activities differently or varies from one another (Santrock \& Santrock, 2007; Slavin, 2011; Willingham et al., 2015). The differences in students in their learning activities are seen through differences in performance, the ability to receive information, learning speed, learning methods, behaviour, actions, perspective skills, cognitive processing, information management, and sensory diversity (Huda \& Learning, 2014; Mulyati, 2015; Mustaqim \& Abdul, 2010). The results of this difference affect the performance level of students so that in implementing learning in schools, teachers must pay attention to these differences (Riener \& Willingham, 2010).

The success in the learning for each student is different, so that this difference in ability is important to pay attention to in learning (Maric et al., 2015; Sabran, 2016). Different groups of students who are given the same assignment at a predetermined time can get different results (Mustaqim \& Abdul, 2010). The difference in students' ability to use certain methods or methods to absorb information in the material determines their success in their learning activities. The easiest and fastest way students have in their learning activities is known as a learning style (Fuad, 2015).

Learning styles describe how individuals can creatively adapt to learning situations by showing a preference for affective, perceptual, cognitive, or behavioural functions (Maric et al., 2015; Peterson et al., 2015). Learning styles can also be interpreted as how someone likes to think, process and receive information or material (Gunawan, 2006). Whichever a person chooses way or method, differences in learning styles show the fastest and best way for each individual to absorb or receive material information (Widayanti, 2013). Learning by using an appropriate learning style will make learning activities effective (Mulyati, 2015).

Learning styles are an important aspect of learning activities that both teachers and students need to pay attention to because learning will be effective with learning styles. Learning styles are the key to student success in learning (Mulyati, 2015). Several certain dimensions (abilities, knowledge, interests) differ from one another influence on learning (Riener \& Willingham, 2010). Learning methods and styles are related to students' performance on learning so that success in learning can be determined by learning methods (Balakrishnan \& Gan, 2016). Learning styles have important implications in learning because student achievement results from teacher teaching and student learning styles (Fuad, 2015; Willingham et al., 2015). Therefore, teachers should understand the learning styles possessed by their students before applying their teaching methods. Teachers must know what is in their students and what treatment they need. The suitability of teacher teaching methods with student learning style preferences will make it quick and easy for students to accept the teacher's 
material and create a pleasant learning atmosphere. The suitability of teacher teaching methods with student learning styles will increase the learning process's effectiveness (Nasution, 2010).

Students need to be helped to develop themselves at school and find good learning attitudes and habits. One important aspect is helping students to find the right way of learning (Sukardi, 2002). The wrong way of learning results in the subject matter not being mastered, so that following the learning process will experience difficulties (Widayanti, 2013). The importance of teachers and students knowing learning styles is based on the effectiveness of the classroom's learning process.

Pratiwi, Joharman, \& Suyanto (2018) said that only about $30 \%$ of students succeeded in taking lessons by the teacher's teaching method applied. The rest, which is about $70 \%$, experienced difficulties in participating in learning. This was because the teacher's teaching method was not by students' learning styles. For this reason, teachers' teaching strategies and methods need to be adapted to the characteristics of student learning styles in order to create active and effective learning in the classroom.

Wlediarti argued in his research that in senior high schools (SMA) in particular, learning styles were important because students had studied the scientific field of interest (specialization). This means that students have specialized in subjects according to their talents and interests. At this stage, students must understand and recognize their potential to maximize the talents of their interest in the specialization they choose. One way is to recognize and understand their learning styles. Students who understand their learning styles will recognize their own strengths and weaknesses in learning (Wledarti, 2018).

Understanding student learning styles, especially in senior high schools (SMA), is one of the determinants of student success in participating in the learning process. This is because the learning style concerns how a person can receive and process information into knowledge (Hasibuan \& Ramdhani, 2016). Thus, the learning style is a very supportive factor for student success in following the academic process at school. In general, teachers teach classically and do not pay much attention to students' learning styles in the classroom, whereas recognizing students' learning styles will help in designing learning. For that, students and teachers need to pay great attention to learning styles. However, what happens in schools, the importance of learning styles has not received much attention from teachers, even by students themselves (Wledarti, 2018).

The problems experienced at school are related to learning styles, need practical solutions, which are easy to apply and use. To answer these problems, we need a contemporary breakthrough. This innovation follows the development and advancement of technology and considers the needs of students in schools.

The development of Information Technology is currently very rapid and has been widely applied in the school environment. So, in helping students recognize their learning styles, they also need to be developed by taking advantage of IT developments so that their application becomes easier and more efficient. Students are more interested in using media because utilizing media will arouse passion, be more interactive, interesting and increase student interest (Frisby et al., 2014; Mursalim, 2018).

One of the media that is quite popular is the website. The website is an internet-based platform, which provides various multimedia information needed by its users (Social, 2020). Based on information compiled by WeAreSocial, currently, internet users in Indonesia reached 64\% of the total population of 272.1 million people; as many as 175.4 million are active internet users. Of these users, adolescents occupy the secondhighest number of users, in the 18-24 years age range, with a percentage of $30.3 \%$ (Social, 2020). Thus, choosing a website as a medium that can be used to explore student learning styles is the right choice with students' characteristics and needs and in line with current technological developments.

Previous research conducted by Nugroho, Pajow, Liem (2016) showed that the website he developed could help students find out their appropriate learning styles and help lecturers 


\section{$53 \mid$ Jurnal Psikologi Pendidikan \& Konseling Vol. 6 No. 2 December 2020}

obtain information about student learning styles. Development with similar media was also carried out by Pratiwi (2014); Sridiarsih (2014), from this study, obtained results in learning style inventory software that is equipped with a guidebook. However, media development is intended for students as well as junior high school (SMP) students. Thus, in this study, learning style tracing media will be developed to be used specifically in senior high schools (SMA).

This learning style search media was developed based on a website called Learning Spring, which stands for Student Learning Style Search. This media was developed by updating some of the results of previous research on users' aspects, usage, analysis results, capacity, appearance and completeness in the form of a guidebook. The ease of this Learning Spring is that students can access it anytime and anywhere via a smartphone or laptop connected to the internet network. With Learning Spring, students can find out their dominant learning style preferences, understand their strengths and weaknesses, get information about learning methods and methods appropriate for them.

\section{METHOD}

This study uses a Development Research approach. The development model refers to the ADDIE Model, namely Analysis, Design,
Development, Implementation and Evaluation. In this study, development was carried out in only three main stages: the analysis stage, the design stage, and the development stage. This model is used for various development forms, such as models, learning strategies, and media development (Branch, 2009; Winarni, 2018). The research conduct at SMA Imam Asy-syathiby Gowa for the 2019/2020 academic year after an initial survey conducted to determine the needs and description of the implementation of counselling guidance services in schools. The reason for choosing the research location considered by the research objectives, school facilities, school establishment and other supporting factors - data collecting method through interviews and questionnaires with qualitative and quantitative data analysis. The questionnaire consists of two types: a need assessment questionnaire with a yes-no answer and a trial questionnaire (validity and practicality) with a Likert scale. The questionnaire adapted from the BSNP Learning Material Development Assessment Instrument with content, presentation, language, graphic and application feasibility assessment. The trial was carried out in two stages, namely (1) One to one Trial for validation tests and (2) Small Group Trial for limited testing. Trial subjects to experts (material and media) and practitioners, and limited groups (teachers and students)

Tabel 1. Aspects and Components of Assessing Validity and Practicality of the media

\begin{tabular}{|c|c|c|}
\hline Aspects & Assessments Component & Subjek \\
\hline $\begin{array}{l}\text { Feasibility of } \\
\text { Content }\end{array}$ & $\begin{array}{l}\text { The scope of the material, the accuracy of the material, the } \\
\text { suitability of the material, the relevance, the up-to-date of } \\
\text { the material, and the legal compliance of Material Experts, }\end{array}$ & $\begin{array}{c}\text { Material } \\
\text { Expert/practicioner }\end{array}$ \\
\hline Presentation & $\begin{array}{c}\text { Presentation techniques, supporting material presentation, } \\
\text { attractiveness of appearance, and completeness of } \\
\text { presentation of Material }\end{array}$ & $\begin{array}{l}\text { Experts, Media } \\
\text { Experts, } \\
\text { Practitioners } \\
\text { Language } \\
\end{array}$ \\
\hline Language & $\begin{array}{l}\text { The appropriateness of the student's development, } \\
\text { readability, conciseness, straightforwardness, interactive, } \\
\text { language rules, and the use of terms, symbols or icons }\end{array}$ & $\begin{array}{c}\text { Material } \\
\text { Expert/practicioner }\end{array}$ \\
\hline Layout & $\begin{array}{l}\text { Design layouts, layouts, illustrations, typography, and } \\
\text { colors }\end{array}$ & Media Expert \\
\hline Application & Ease of use and usefulness & $\begin{array}{l}\text { Practicioner, } \\
\text { teachers. students }\end{array}$ \\
\hline
\end{tabular}




\section{RESULT AND DISCUSSION}

A preliminary study regarding the need to develop PEGAS BELAJAR as a medium for tracing student learning styles in high schools obtains a description of the problem, urgency and significance level of the media's need to be developed. The description of the level of this need was obtained through interviews with counselling teachers and continued by distributing a need assessment questionnaire to class XI IPA, namely class XI IPA 1 with 19 students and class XI IPA 2 with 20 students.

The interviews conducted with counselling teachers show that counselling services, especially learning information services, have not been carried out properly, needs analysis has not been carried out, especially in identifying student learning styles. There is no media or data related to student learning styles. Meanwhile, there are many problems. Students experience in the classroom related to learning styles such as students paying less attention to the teacher's explanation, the difficulty of students understanding the material and their lack of involvement in the class.
Furthermore, through distributing questionnaires to students, information was obtained that $77 \%$ of students did not know their learning styles, $74 \%$ needed guidance and counselling teachers to find out their learning styles, and $82 \%$ needed media to help them identify their learning styles. Thus, developing the PEGAS BELAJAR website as a medium for tracing student learning styles.

PEGAS BELAJAR website is an ITbased guidance and counselling media with a guidebook. Pegas Belajar contains a static website display, which is a website page that does not change (static) appearance, consisting of pages for home, guide, about and contact views. Home view is the initial view when visiting the website, where on this page displays learning style tests, types of learning styles David Kolb, statistics, testimonials and contacts. Manual pages to assist users in using learning springs containing downloadable manuals. The page contains information about the learning spring and its developer. A contact page contains information such as address and forms for sending messages via email. Figure 1 below is a look at the PEGAS BELAJAR website:

Figure 1. Appearance of Learning Spring Website as a Media for Tracing

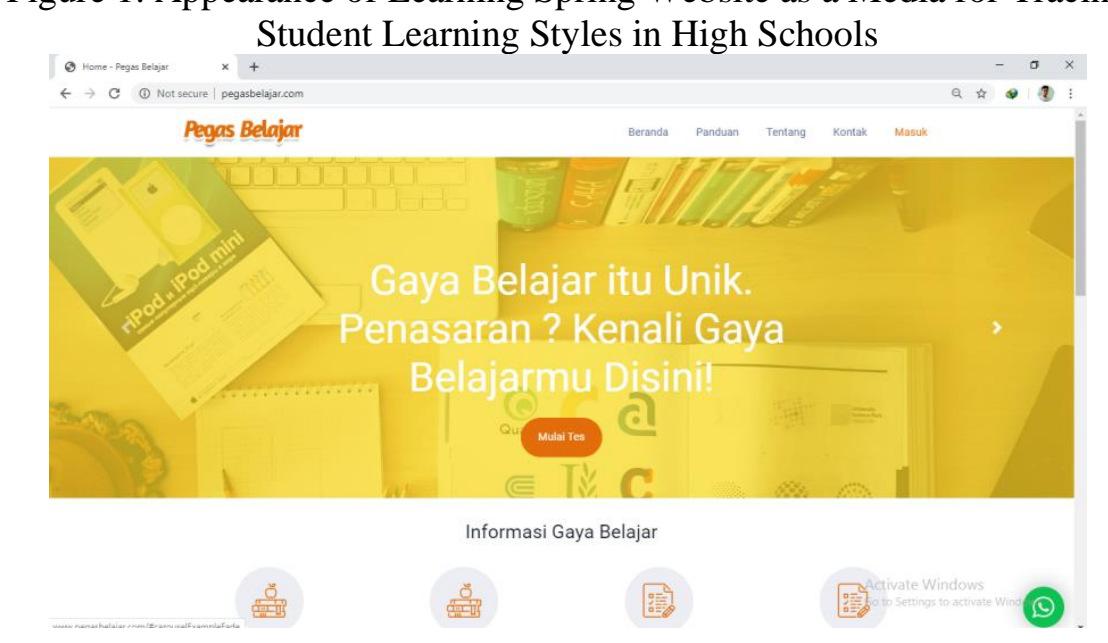

This learning website registered on domainesia.com with the website domain www.pegasbelajar.com, equipped with cloud hosting-based storage. This learning spring website was created with the Codelgniter web framework, using the PHP 7.2 programming language, the Google Font API script font and jQuery 3.2 javascript libraries.

The Guidebook is designed with the book's standard size, which is $15 \times 21 \mathrm{~cm}$ (A5). It has 55 pages, consisting of a Front-Cover page, Acknowledgments, Table of Contents, Chapters, 
and Bibliography. The chapters consist of Chapter 1 Introduction, Chapter 2 Learning Styles Experiential Learning, Chapter 3 Learning Spring as a Media for Tracing Student Learning
Styles, Chapter 4 Guidelines for Using Learning Springs and Chapter 5 Closing. The manual display is shown in Figure 2 below:

Figure 2. The appearance of the Learning Spring Guide Book as a Media for Tracing Student Learning Styles in High Schools

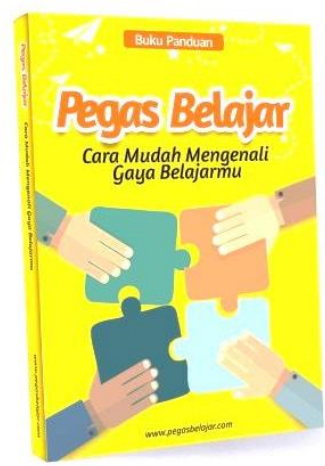

The description of the level of validity and practicality of the media is obtained through two trial stages, namely 1) One to one trial for validation tests and 2) Small group trials for practicality tests. The level of validity and practicality is determined based on certain categories as in Table 2 below:

Table 2: Criteria and Categories for the Level of Validity and Practicality of Learning Spring

\begin{tabular}{ccc}
\hline No. & Percentage $(\%)$ & Category \\
\hline 1 & $81-100$ & Very High \\
\hline 2 & $61-80$ & High \\
\hline 3 & $41-60$ & Average \\
\hline 4 & $21-40$ & low \\
\hline 5 & $1-20$ & Very low \\
\hline 6 & 0 & Not accepted \\
\hline
\end{tabular}

To obtain data on the validity of Pegas Belajar, the tests conducted on experts, consisting of material experts, media experts and practitioners with an overview of the validity level assessment as in Table 3 below:

Table 3. The description of the level of validity of learning springs as a medium for tracing student learning styles by material experts, media experts and practitioners

\begin{tabular}{ccccc}
\hline \multirow{2}{*}{ No } & Assessments Components & \multicolumn{3}{c}{ Subjects } \\
\cline { 3 - 5 } & $\begin{array}{c}\text { Material Expert } \\
(\%)\end{array}$ & Media Expert (\%) & Pacticioners (\%) \\
\hline 1 & Content Feasibility & 84 & - & 96 \\
\hline 2 & Presentation & 84 & 69 & 96 \\
\hline 3 & Language & 78 & - & 100 \\
\hline 4 & Layout & - & - & - \\
\hline 5 & Application & - & 71 & 98 \\
\hline \multirow{2}{*}{ Average of expert assessment } & 82 & $($ High $)$ & (Very High) \\
\hline & Validity & & & 83 (Very High) \\
\hline
\end{tabular}


Based on the counselling guidance material expert's content validity test (Dr. Abdullah Pandang, M.Pd), the feasibility of the content, presentation, and language of the learning spring had adequate conceptual feasibility. The media's validity test to educational technology media experts (Dr. Muh Rais, M.T., M.P) obtained the results that the presentation and graphics of the media developed had met the valid media requirements. The practitioner (Nirwana Masdar, S.Pd., M.Pd) assess the content's appropriateness, the attractiveness of appearance, the suitability of language, the accuracy of purpose and usefulness. From the practitioner's assessment results, the Pegas Belajar website has feasibility, accuracy, suitability, attractiveness, and good usefulness for students and counselling teachers in schools.
Overall the assessment obtained from experts and practitioners shows satisfactory results with the average level of media validity in the very high category $(83 \%)$ and appreciates the development of learning spring websites as a medium for tracking student learning styles for use in schools. However, the learning spring website and this guidebook still have to be revised according to the suggestions given to perfect the media so that it can be even better. Responses and input from the test results to experts are used as the basis and material for media improvement before being tested in schools directly.

Furthermore, to obtain data on the practicality level of learning spring media, limited trials were carried out on teachers and students in schools with a description of the assessment as in Table 4:

Tabel 4. An overview of the level of practicality of learning springs as a medium for tracing student learning styles by counseling teachers and students

\begin{tabular}{ccccc}
\hline No. & Subject & Total Subject & Percentage $(\%)$ & Category \\
\hline 1 & Teachers & 1 & 100 & Very High \\
\hline 2 & Students & 15 & 94 & Very High \\
\hline & Average & & 97 & Very High \\
\hline
\end{tabular}

Based on the limited trials conducted, the results showed that the counselling teacher and students gave a positive response to this learning spring website's existence. This evidence shows the percentage level of the assessment from students, namely $100 \%$ assessing it is easy to use, $100 \%$ assessing it is interesting, and $93 \%$ assessing this media is easily accessible. Thus, it can be said that media development by utilizing these technological developments makes it easier to use, effective, and attracts its users' interest. Students also assess that this learning spring reveals learning styles that are appropriate to them. As the assessment results, as many as $93 \%$ of students rated the media to help identify their learning styles and $80 \%$ of students rated the media to reveal the learning styles of students according to themselves.

This finding is in line with the results of research conducted by Nugroho et al. (2016) that the web application is a new platform that is easy to access online and can help determine the appropriate learning style for its users. The responses and suggestions given by counselling teachers and students for the Pegas Belajar website show that the website is easy and helps students reveal their learning styles, especially in identifying student learning styles by counselling teachers in schools. Also, the website has good acceptance that the Pegas Belajar website can be a medium for tracing student learning styles in senior high schools.

After going through this limited trial stage, revisions for the linguistic and graphic aspects conducted to improve product development. The final product founded as the Pegas Belajar website for tracing student learning styles in high school.

\section{CONCLUSIONS AND SUGGESTIONS}

This study's conclusions are: 1) Counsellors and students at school show a high 
level of need for learning springs as a medium for tracing student learning styles in high schools, 2) The Prototype of Pegas Belajar website consists of two forms, namely websites and guidebooks. The website designed using the Codelgniter framework, the PHP 7.2 programming language, the Google Font API script font and the jQuery javascript libraries version 3.2, with a manual for teachers and students consisting of 56 pages measuring A5, 3) the level of validity and practicality of learning springs as a search medium Student learning styles through the expert, practitioner and the limited test shows that the validity level of the learning spring is in the very high category. The level of practicality is also in the very high category.

It concluded that the Pegas Belajar website is accepted and used to help students recognize and understand their high school learning styles. The next researcher will develop this media to track student learning styles to provide more comprehensive benefits. Researchers who intend to develop this research can test the effectiveness and test subjects with different backgrounds and characteristics, including a more significant number of subjects.

\section{REFERENCES}

Abdullah, R. (2015). Urgensi Disiplin dalam Pembelajaran. Lantanida Journal, 3(1), 1833.

Balakrishnan, V., \& Gan, C. L. (2016). Students' learning styles and their effects on the use of social media technology for learning. Telematics and Informatics, 33(3), 808821.

Branch, R. M. (2009). Instructional design: The ADDIE approach (Vol. 722). Springer Science \& Business Media.

Frisby, B. N., Weber, K., \& Beckner, B. N. (2014). Requiring participation: An instructor strategy to influence student interest and learning. Communication Quarterly, 62(3), 308-322.
Fuad, A. J. (2015). Gaya belajar kolb dan percepatan belajar. Psyhology Forum UMM: Seminar Psikologi Dan Kemanusiaan, 1-6.

Gunawan, A. W. (2006). Genius learning strategy. Jakarta: Pustaka Utama.

Huda, M., \& Pembelajaran, M. M. P. D. (2014). Pustaka Pelajar. Yogyakarta.

Khalil, M., \& Ebner, M. (2015). Learning analytics: principles and constraints. EdMedia + Innovate Learning, 1789-1799.

Kolb, D. A. (2014). Experiential learning: Experience as the source of learning and development. FT press.

Maric, M., Penger, S., Todorovic, I., \& Djurica, N. (2015). Differences in learning styles: a comparison of Slovenian Universities. Procedia-Social and Behavioral Sciences, 197, 175-183.

Maunah, B. (2014). Psikologi Pendidikan. IAIN Tulungagung Press.

Mulyati. (2015). Identifikasi Gaya Belajar Siswa Kelas V SD Se-Gugus 3 Kecamatan Pengasih Kabupaten Kulon Progo Tahun Ajaran 2014/2015. Jurnal Pendidikan Guru Sekolah Dasar, IV(13), 1-7.

Mursalim, M. (2018). Pengembangan Media Bimbingan Konseling. Penerbit Indeks.

Nasution. (2010). Berbagai Pendekatan dalam Proses Belajar dan Mengajar. Bumi Aksara.

Nurjan, S. (2016). Psikologi Belajar. Wade Group.

Parnawi, A. (2019). Psikologi Belajar. Deepublish.

Peterson, K., DeCato, L., \& Kolb, D. A. (2015). Moving and learning: Expanding style and increasing flexibility. Journal of Experiential Education, 38(3), 228-244. 
Pratiwi, D. (2014). Gaya belajar dominan pada siswa berprestasi dalam kegiatan siswa yang memiliki gaya belajar di SD Negeri 2 Gombong tahun ajaran 2013/2014. Jurnal FKIP, 7(3), 1-20.

Riener, C., \& Willingham, D. (2010). The myth of learning styles. Change: The magazine of higher education.

Sabran, R. (2016). Perbedaan individual salah satu faktor yang perlu diperhatikan dalam proses belajar mengajar. Lentera: Jurnal Pendidikan, 11(2).

Santrock, J. W., \& Santrock, J. W. (2007). Psikologi Pendidikan edisi kedua. Kencana Prenada Media Group.

Slavin, R. E. (2011). Psikologi pendidikan teori dan praktik. Jakarta: Indeks.

Sridiarsih, L. N. (2014). Pengembangan Software Inventori Gaya Belajar bagi Siswa Sekolah Menengah Pertama (SMP). Jurnal BK UNESA, 4(3), 630-640.

Sukardi, D. K. (2002). Pengantar Pelaksanaan Program Bimbingan dan Konseling di Sekolah. Rineka Cipta.

Widayanti, F. D. (2013). Pentingnya Mengetahui Gaya Belajar Siswa Dalam Kegiatan Pembelajaran Di Kelas. Erudio Journal of Educational Innovation, 2(1).

Willingham, D. T., Hughes, E. M., \& Dobolyi, D. G. (2015). The scientific status of learning styles theories. Teaching of Psychology, 42(3), 266-271.

Winarni, E. W. (2018). Teori dan Praktik Penelitian Kuantitatif, Kualitatif, PTK, R\&D. Jakarta: Bumi Aksara. 